\title{
Project Financing Models for Toll Road Investments: A State-of-the-Art Literature Review
}

\author{
Lukas B. Sihombing ${ }^{1{ }^{*}}$, Yusuf Latief ${ }^{1}$, Ayomi D. Rarasati ${ }^{1}$, Andreas Wibowo ${ }^{2}$ \\ ${ }^{1}$ Department of Civil Engineering, Universitas Indonesia, Depok, 16424, West Java, Indonesia \\ ${ }^{2}$ Agency for Research and Development, Ministry of Public Works and Housing, Cileunyi, 40393, West Java, Indonesia
}

Copyright $\bigcirc 2018$ by authors, all rights reserved. Authors agree that this article remains permanently open access under the terms of the Creative Commons Attribution License 4.0 International License

\begin{abstract}
In greenfield toll-road projects, financial sustainability has been a major issue. Many toll roads cannot be operated. Although most of Indonesia's 24 toll road concessions have already been signed by the Toll Road Authority, most of them were caused by financing problems. Three problems have been identified as potential sources of this unsustainability, such as the uncertainty of long-term project revenues, budget constraints provided by the government, and inadequate government support for land acquisitions. This paper aims to investigate the state-of-the-art innovative financing models recently introduced to address financial problems by using a desk study and meta-analysis. The findings are an earmarked tax revenue system, deep discount bonds, take-out financing, tax increment financing, land leases, deferred debts, and private donations.
\end{abstract}

Keywords Toll Road, Innovative Financing, Desk Study, Meta-analysis

\section{Introduction}

The project is a legally and economically independent project company, either as independent assets under an economic unit or as a special purpose vehicle (SPV); it services the debt from the project cash flow alone, also known as project finance. At the same time, it is also known as non-recourse; the lender cannot recourse to the parent company of the borrowing SPV, even if the project goes wrong [1, 2]. In addition, risks and rewards are properly traded-off, so careful financial engineering must be carried out to ensure that the SPV is economically strong to meet its obligations to both creditors and shareholders [3].

A project financing scheme application was used in English road systems in the 18th and early 19th centuries. It is actually not a new concept, especially for a public infrastructure project [4]. The Government of Indonesia (GoI) built the $60 \mathrm{~km}$ Jakarta-Bogor-Ciawi (Jagorawi) toll road in 1978. It was well-known as the first application of project financing in Indonesia [5]. At that time's currency value, the GoI spent about IDR 350 million per kilometer with a combination of foreign loans and government budget financing [6]. At present, the toll road financing model uses either a build-operate-transfer (BOT) contract or a public-private partnership (PPP) [7].

In fact, the construction and operation of new toll roads has developed very slowly in Indonesia. Some factors seem to stand out more than others, one of which is financial sustainability. These factors explain why the signs of progress are so slow. For instance, the Toll Road Authority has already signed 24 toll road concessions, but they cannot be put into operation because they face financing problems.

Therefore, various potential sources of financial unsustainability can be identified, such as the uncertainty of long-term project revenues, budget constraints provided by the government for toll roads [8], inadequate government support for land acquisitions [9, 10], a lack of toll road financing itself $[11,12]$ and low traffic estimates [13]. According to Halpin and Senior [14], alternative gap financing is needed to fill the gap. The objective of this paper is to present state-of-the-art literature related to project financing models for toll roads.

\section{Sources of Funds}

Various stakeholder organizations are often involved in project finance, as well as many having complex contractual arrangements among them. As shown in Figure 1, it illustrates a simplified project finance structure. Debt is also typically characterized by high leverage, with an average of $70 \%$ or even more. The debt generally comes from four sources: bank financing (domestic and foreign), insurance companies, conduit-loan securitization, and single-asset securitization [15]. 


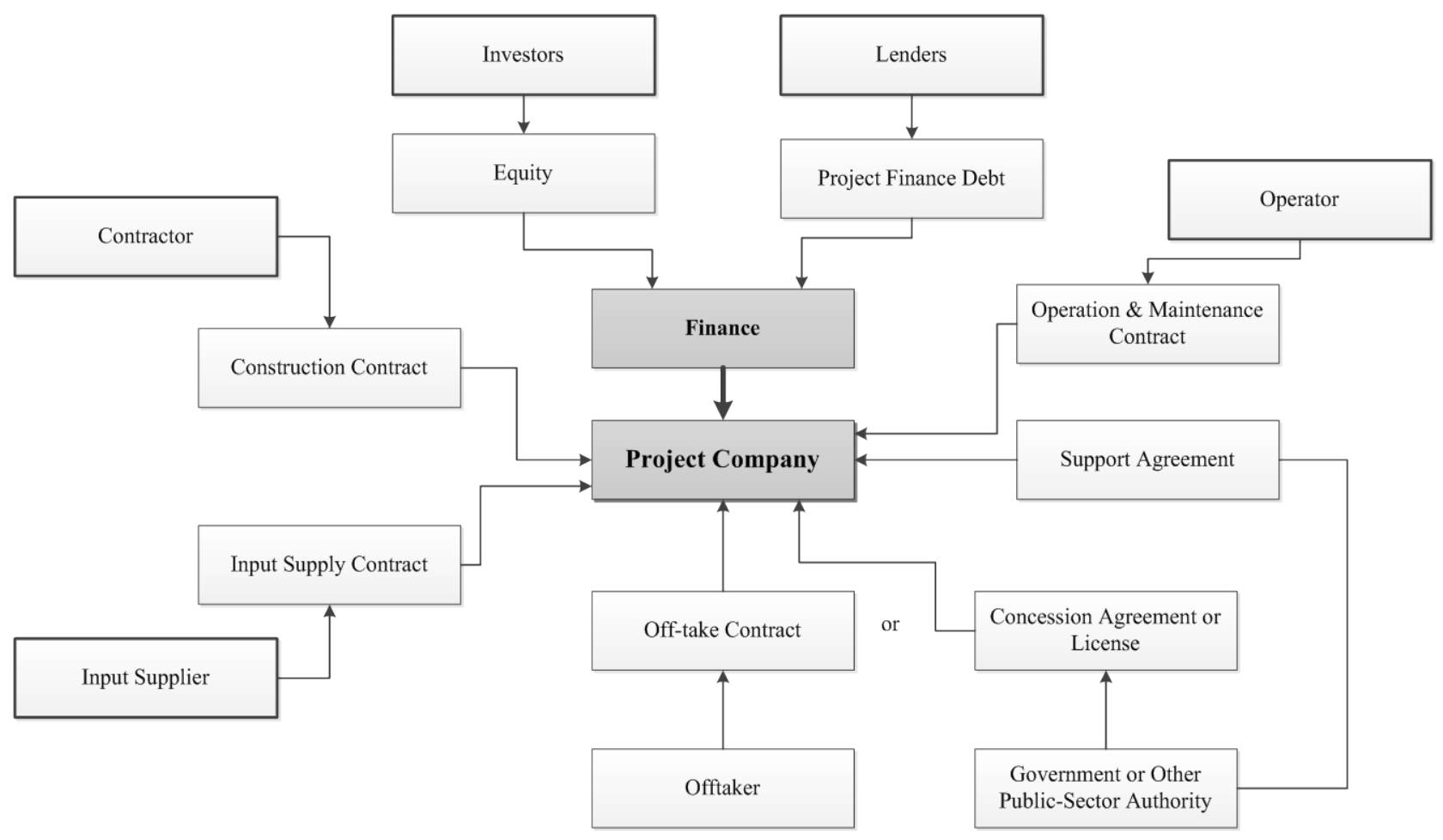

Figure 1. Simplified project finance structure [4]

In addition, serious consideration of cash flow estimates and risk analysis will be given by banking institutions of a non-recourse nature in project finance. Then, qualitative or quantitative approaches or both of them will be employed by banks to analyze the default risks [16]. For large projects, especially for power industries, oil and gas companies, and transportation industries, financial advisers and lead managers are also usually assigned by banks to help underwrite debt and place them in capital markets, such as in the USA, Europe, the Middle East, and Africa [16].

Equity is the second source of capital used to finance large projects. Meanwhile, entities that are usually linked with a core business or have some connection are the project's equity shareholders (i.e. the project sponsor), such as construction companies, equipment suppliers, maintenance agencies, or construction contractors [17]. In addition, country risks, project structure, years of investment, and project costs will influence private equity investors' decisions to invest in an infrastructure project [17]. Therefore, the cash distribution received by equity investors will depend on the expected residual value of the project or the profitability of the project.

\section{Literature Review}

A literature review is defined as "a systematic, explicit, and reproducible method for identifying, evaluating, and synthesizing the existing body of completed and recorded work produced by researchers, scholars, and practitioners"
[18]. In addition, Fitt [19] stated that it remains a gap in understanding the process of how future scholars for their future roles are prepared for the purpose of the literature review. These definitions emphasize the review process as well as the desired results.

Furthermore, to analyze the content of a literature review, we can use qualitative and quantitative techniques to find the structural and content criteria [20]. Then, a literature review can identify the conceptual content of the domain and may even contribute to the development of the theory as argued by Harland et al. [21]. In the literature review trends, there are several unnoticed critical analyses of the research papers. However, the challenge is the development of the domain analyzed using the whole literature. Therefore, to provide comprehensive reviews within the defined boundary, some delimiting criteria are needed to make it possible.

A systematic review involves a number of discrete steps: devising a question formulation; finding studies and exclusions of criteria; making an appraisal and selection of studies (locate studies, select studies, assess the quality of the study, extract data); making a summary and synthesis of relevant studies (analyze and present the results); and interpreting the results and determining the applicability of the results $[22,27]$.

According to Mayring [23], the procedure of the paper's methodology is to conduct the objectives of the paper here, so that it presents the research trends of the project financing models. In order to enhance the level of understanding, the research question introduced to guide the review process is "What is the current status of the 
literature addressing the major investment project issues causing financing gaps in toll road investment scheme financing models?"

\subsection{Literature Collection and Boundary Identification}

Literature was initially surveyed from various publication sources that focused on project financing in toll road investments, including technical papers from peer-reviewed journals, conference proceedings, white papers, presentation materials from industry, and master's or doctoral theses. The preliminary criteria adopted to include an article are that it was published over the period of 1999-2017 and addressed toll road investment scheme financing models and issues.

\subsection{Content Analysis}

The collected literature was presented in this section as the content analysis. To perform this analysis, Mayring [23] suggested the following four-step process:

- Step 1. Material collection: collecting and then being subjected to delimiting criteria of research papers from all sources related to infrastructure financing, especially toll road project financing.

- Step 2. Descriptive analysis: analyzing the selected papers (e.g. the number of publications per year) to provide the basis for a theoretical analysis.

- Step 3. Category selection: the collected material is categorized; then, select the structural attributes and the corresponding analytical categories. To constitute the analytical category as structural attributes, perform the major topics of the analysis. The structural attributes are, namely, geographical location, problem context, methodology, and product.

- Step 4. Material evaluation: to find relevant issues and trends in the literature, the structural attributes are a basis to analyze the collected papers. Within the structural attributes, perform a detailed analysis of the papers.

Figure 2 shows the process of analyzing the detailed representation (steps 3 and 4), and the purpose of the analysis can be seen in the feedback loop.

However, an inductive or a deductive approach can be used to define the structural attributes and the corresponding analytical categories. In addition, before formulating the criteria for the definitions, we derive the theoretical background and research questions. Examples and coding rules will give explicit definitions, which determine exactly under what circumstances a text passage can be used as a coding agenda [25]. Therefore, it is better to use both approaches iteratively [24].

Finally, this research has to be validated. It is based on the guidelines provided by Kassarjian [26], the category choices, the content units, an examination of the measurement units, the categories, the sampling procedures, and whether the results are enhanced or diminished by the likelihood of valid inference. A review of the other topics is done by forming the referred constructs.

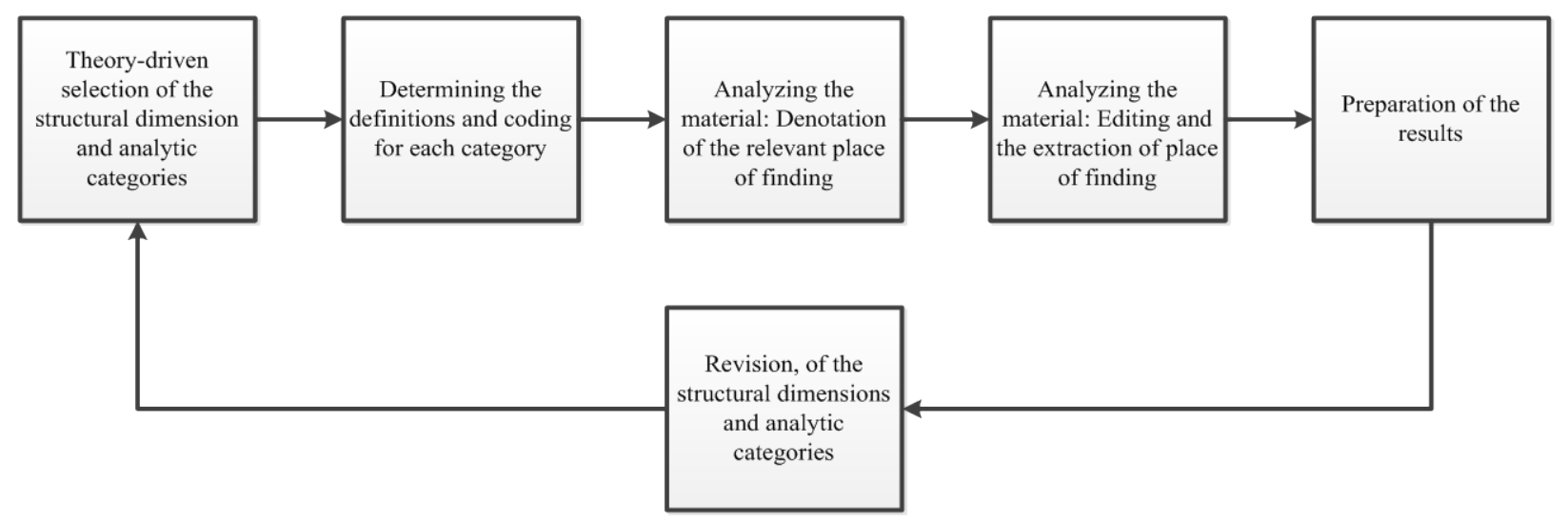

Figure 2. Step wise representation of a structured content analysis 


\section{Segmentation of the Research and Overview}

To qualify the research papers for the research locations, the delimitation criteria were analyzed. The current status of the toll road financing model (TRFM) literature was evaluated to make the effort of researchers and practitioners from various disciplines. A total of 29 articles met the criteria and were used for further analysis. Table 1 presents the list of the journals that address the financing model issues for toll road infrastructure. It is evident that most of the journals (i.e. 24) are either from infrastructure project financing or economic and regulation management.

\subsection{Infrastructure Project Financing Journals}

Infrastructure project financing was specifically addressed through these journal publications, although there may also be problems related to infrastructure project financing (IPF). These journals address the IPF issues from a TRFM perspective. It published 29 papers that had been reviewed, but only 15 papers were available. This shows that many researchers have attempted to solve project financing problems in the toll road sector. Here, the characteristics may or may not be the product of much concern since the main objective is project finance excellence. In such a scenario, the chances of theory development, specifically for toll road project financing models, are quite less. To solve the problems in question, it may be applied based on the existing theories that have already been done. Thus, toll road project financing models exclusively may not be addressed in most of the papers. In comparison with the total publications in these journals, the percentage of papers published in the journals addressing toll road project financing models is negligible. There are only 18 papers published in 15 journals from a period of 18 years. This shows that, although there is an interest in addressing the toll road project financing models, the total amount of research conducted is minimal.

Table 1. List of journals reviewed and the number of papers from 1999-2017

\begin{tabular}{|c|c|}
\hline Name of Journal & Number of papers published \\
\hline \multicolumn{2}{|l|}{ Infrastructure Project Financing } \\
\hline The Journal of Structured Finance & 1 \\
\hline Finance and Investment in Japan & 1 \\
\hline Journal of Financial Management of Property and Construction & 2 \\
\hline Public Finance and Management & 1 \\
\hline Transportation & 1 \\
\hline Australasian Transport Research Forum (ATRF06) & 1 \\
\hline Brookings-Wharton papers on Urban Affairs & 1 \\
\hline The IUP Journal of Infrastructure & 2 \\
\hline Journal of Construction Engineering and Management & 1 \\
\hline Engineering, Construction and Architectural Management & 1 \\
\hline Built Environment Project and Asset Management & 2 \\
\hline Independent Journal of Management \& Production & 1 \\
\hline Iranian Journal of Management Studies & 1 \\
\hline Journal of Financial Management of Property and Construction & 1 \\
\hline Institute of Transportation Engineers. ITE Journal & 1 \\
\hline \multicolumn{2}{|l|}{ Economics \& Regulation Management } \\
\hline Network Spatial Economics & 1 \\
\hline Journal of Economic Cooperation and Development & 1 \\
\hline Regulation & 2 \\
\hline St. John's Law review & 1 \\
\hline International Journal of Management Research and Review & 1 \\
\hline Management Research and Practice & 1 \\
\hline Public Administration Research & 1 \\
\hline Review of Integrative Business and Economics Research & 1 \\
\hline \multicolumn{2}{|l|}{ Others } \\
\hline Thesis Master MIT & 1 \\
\hline Ministry of Finance Paper & 1 \\
\hline
\end{tabular}




\subsection{Economics \& Regulation Management}

These journals may also cover infrastructure project financing issues, which specifically address the financing models for toll roads. Only eight of these journal publications address infrastructure project financing (IPF). There has been little interest on economic and regulation management research in addressing project financing problems in toll roads, as indicated in the findings. Dividing the number of papers by the number of coverage years, results in, on average, less than one paper published a year in this specific area. Moreover, a quarter (2 out of 8 ) of the papers appeared in a specific journal (Regulation), which shows that there is an overall gap in the infrastructure project financing publications to address the problem.

\subsection{Other Journals}

Papers covering toll road projects due to the financing model issues have been published in these journals, although they have not focused on TRFMs or IPF issues. The fact that only two papers out of 29 are published in these journals shows that there are few papers on IPF in economics \& regulation management journals. On the other hand, the issue of IPF in TRFMs is not included in the objectives of these journals because none of the journals has published more than one paper for over 18 years. Either due to the broad boundaries of some of the journals or the lack of a dedicated journal for TRFMs may be attributed to the lack of paper publications in these journals.

The trend of TRFM literature over the last 18 years, as shown in Figure 3, presents the annual publication frequency of the total papers combining all the issues addressed. It is evident from Figure 3 that lately there is an increasing interest in addressing the issues in toll road project financing models. As the graph does not linearly increase over the years, it is possible that this growth may not be fully credited to the increase in the number of total publications every year. Moreover, the sudden increase in the number of papers from 2006 can be attributed to the global factors that have attracted the attention of researchers and practitioners in this field, which includes the project financing crises. Since 2006, a drastic decrease up to zero has been shown by the toll road project financing models. The increase of toll road project financing models had an impact four times between 2008 and 2009. Therefore, the increase in the number of research papers seems to be a reflection of these critical factors. These factors did not seem significant in the period from 1999-2004, since the maximum number of papers published in any given year is two, which is quite minimal. It is interesting to note that although toll road project financing models have always been a major concern, only recently have they gained the attention of researchers. With the increasing population, there is a high possibility that this issue will get more attention in the future.

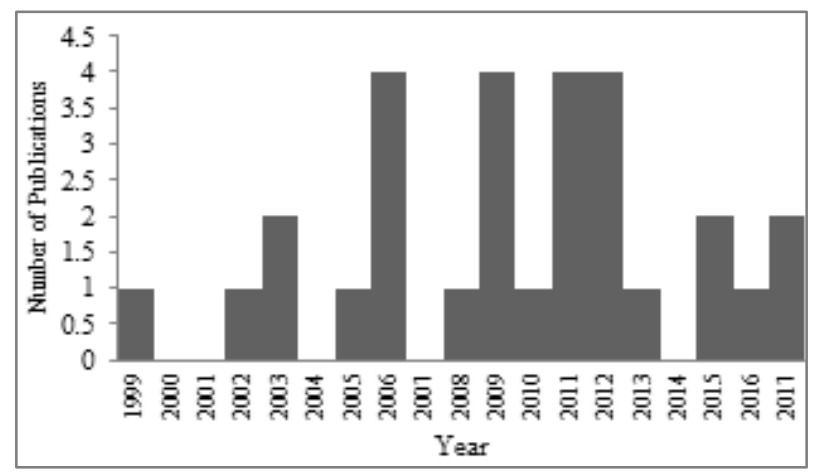

Figure 3. Trend of toll road project financing model literature over the years

As shown in Figure 3, the volume and continuity of research papers will surely attract the attention of publishers and editors towards the lack of journal publications addressing the toll road project financing model issues. In the future, special issues addressing project financing models shall be reflected from the effects of lacking a specific journal. It was also found that a lot of papers have addressed a country-specific issue. In these country-specific publications, the USA and India gained a majority of the attention, with a limited focus on China, Japan, and Indonesia. One of the reasons for this may be because research in infrastructure project financing as compared to the toll road infrastructure sectors in other countries can be funded by the infrastructure sector in those countries. Table 2 presents the details of the country-specific studies. The studies that are not very specific to any particular country or region are categorized as generic. This is not at all surprising since it is quite similar to the country rating according to SCImago (www.scimagojr.com). The little deviation is explicit due to the economic orientation of the few countries towards toll road infrastructure. Besides that, most of the studies are "generic" for the toll road project financing models, i.e. addressing no specific country.

\section{Classification Based on Problem Context}

Now we consider the papers addressing the toll road project financing models to classify and review the research based on infrastructure project financing issues, which cause a financing gap. The major issues are classified into three categories, according to the categorization by the practitioners and academicians: financing, delivery system, and revenue.

In addition to these three major categories of infrastructure project financing, there are certain other issues which are operational in nature but do not fit into any of these three categories. For example, there is the feasibility of toll roads. This issue has been put into a fifth category called "others". In the following sub sections, a 
review of the literature on these issues is presented.

Table 2. Number of studies across countries

\begin{tabular}{|c|c|}
\hline Country & Number of Studies \\
\hline USA & 7 \\
\hline UK & 1 \\
\hline China & 2 \\
\hline Korea & 1 \\
\hline Japan & 2 \\
\hline Hong Kong & 1 \\
\hline Canada & 1 \\
\hline Australia & 1 \\
\hline India & 5 \\
\hline Turkey & 1 \\
\hline Indonesia & 3 \\
\hline Nigeria & 2 \\
\hline Pakistan & 1 \\
\hline Columbia & 1 \\
\hline
\end{tabular}

\subsection{Financing}

One of the most researched topics in infrastructure project investment is about the financing problem. In developing countries, infrastructure financing is the biggest problem, especially in metropolitan areas [27]. It becomes even more important in the case of toll road project financing due to the investment sphere. This section classifies and reviews the literature on the financing problem for toll road project financing. The key findings from the financing literature are presented later in this section.

Based on the literature review, it was found that there were financing problems in traditional toll roads such as; in concessions, where an investment combination was loaded in front-loaded investments [28], how to obtain congressional support as a politically attractive alternative as a toll road financing problem [29], the inefficiency of infrastructure projects [30], financial risks for toll road project financing have not been identified, quantified, or evaluated [7], the improvements in toll road development are not similar with the rapid transportation demands and economic growth [31], a lack of understanding of the security stipulation from lenders like a bank [32], a lack of equity amount estimation and rate of return on equity [33], a lack of equity financing and corporate bond market options and, often, overlapping regulations [34].

In addition, urban infrastructure investment financing problems [35], long-term investment funds in infrastructure sectors, including toll roads [36], the relationship between risk factors and equity participation in the structure of BOT contract equity [37], financing instruments that could be used for toll road financing [38], the State's financial limitations to finance toll road infrastructure projects [39], and no internationally recommended best practices in toll road financing with public-private partnerships [40].

\subsection{Delivery System}

Several models for a financing problem analysis have been presented by researchers. The status of research from different perspectives is presented by several reviews in a delivery system. For example, they focused on a delivery system in a private finance initiative (PFI) [41], a comparison of cost efficiency based on project delivery such as design-bid-build (DBB), construction management at-fee (CM-at-fee), design-build (DB), design-build-operate (DBO), and design-build-(finance)-operate (DBFO) for toll road management [42], the relationship between the public-private partnership and leverage lenders [43], as well as the slow delivery process of toll road project and a decrease in new revenue [44].

\subsection{Revenue}

Over the past several decades, researchers have studied various models dealing with the revenue from toll roads. These researchers tried to model the deteriorating characteristics of the toll road financing for revenue management. Some of them are, a comprehensive literature survey of revenue models [45]; and low toll road revenue and congestion [46]. It was found that the revenue of toll roads was also considered by some of the authors.

\subsection{Others}

The issues which are in the problem context domain that will be discussed in this section cannot be included in any of the three categories as described above. For example, the issues include case studies, toll road feasibility [47], and toll road investments [48].

\section{Classification Based on Methodology}

The basis of methodology may also be classified in the literature on TRFMs used in: mathematical modeling, simulations, empirical studies, case research, action research, and general purposes. This helps us to understand TRFMs from a different perspective of a methodological point-of-view. This section maps the methodology used vis-a '-vis the problem context of the TRFMs. The mapping of the papers addressing any problems using the corresponding technique is presented in Table 3. It is noted that any methodology used to solve a problem depends on the problem itself, the availability of data and computational resources, and the comfort levels of the researcher when using that particular methodology. Thus, the mapping is done to find the relationship of the 
methodology with the problem.

According to Dyn [49], modeling is "an activity, a cognitive activity in which we think of how to make models to describe how devices or objects of interest behave." There are three categories of models as follows: physical models, mathematical models, and computer models [50]. Meanwhile, mathematical models can be called simulation, but physical models cannot be called simulation. So, a model is "the general name, whereas a simulation is a specific name given to the computer modeling." This shows that there are five papers that focus on financing and modeling methodology $[37,45,48,71$, 72]. Meanwhile, there are two papers which focus on financing and simulation methodology [7, 33].

Table 3. The number of papers addressing any issues using the corresponding technique

\begin{tabular}{|c|c|c|c|c|c|}
\hline & Revenue & $\begin{array}{c}\text { Delivery } \\
\text { System }\end{array}$ & Financing & Others & Total \\
\hline Modeling & & & 5 & & 5 \\
\hline Simulation & & 1 & 2 & & 2 \\
\hline $\begin{array}{c}\text { Empirical } \\
\text { Studies }\end{array}$ & 1 & 1 & 7 & 2 & 11 \\
\hline Case Study & 1 & 3 & 7 & & 10 \\
\hline $\begin{array}{c}\text { Action } \\
\text { Research } \\
\text { General }\end{array}$ & 1 & 5 & 21 & 2 & 29 \\
\hline Total & 1 & & & & 1 \\
\hline
\end{tabular}

According to Kosorok [51], empirical process methods are "powerful techniques for evaluating the large sample properties of estimators based on semi-parametric models, including consistency, distributional convergence, and validity of the bootstrap." However, of the 29 papers that were studied by the researchers, only one paper used an empirical method [42].

In the TRFM research, case studies have found a special plane, because the case study researches "involves the study of an issue explored through one or more cases within a bounded system" [52]. There are eleven papers in every focus that used a case study methodology, such as [30, 32, 35, 38, 43- 44, 46, 47, 50, 73-74].

According to Marshal, Willson, and de Salas [53], action research is the collaboration between researchers and practitioners to improve a problematic situation of concern. There are ten papers that used an action research general methodology, as follows: $[28,29,31,34,36,39-41,54$, 75].

\section{Classification Based on Product}

The literature on TRFMs can also be classified based on the product studied. As the product is geographically dependent, the availability of government or private funding of the product's origin affects the TRFMs. The number of papers addressing an issue for a particular product is represented in Table 4 . It is evident from Table 4 that mostly financing models are considered as a single product and the problems are addressed on an aggregate level, taking all products as a single product. This is mainly because the overall toll road financing models addressed the effects of a factor on the overall toll road financing models. There are a few cases where an individual factor such as a private finance initiative has been considered. Specific factors such as the user mode selection and an endogenous route through the focus of a revenue study may be attributed to these toll road financing models.

An introduction to TRFMs, a delivery system, and financing focus have gained most of the attention, with less attention being given towards revenue and other focuses of interest. Generally, in the case studies, a product is addressed at the individual and aggregate level, discussing the coordination and integration of related issues. The financing focus of TRFMs has been studied at an aggregate, and in some cases, a disaggregated level. Papers discussing a delivery system generally tried to find the contractual of the delivery system. However, papers also considered a private financing initiative, risk project financing, the uncertainty of the dynamic transportation demand, securitization, the earmarked tax revenue system, social policies and public law value, limited equity, real options, the capital market, and SPV financial strength as a single product in most of the cases. But only at an aggregate level have other issues also been discussed, such as inventory management and transportation.

The TRFMs for all kinds of products cannot follow the same strategy, since toll road financing has a high level of heterogeneity. The rate of deterioration and other physical conditions also vary to a high degree across products, so the delivery system and revenue conditions should also be different for all the products. Table 5 shows the products studied vis-a '-vis the geographical location. It is noted that most of the research has been carried out in developed countries and toll road financing model oriented countries such as the USA. 
Table 4. The number of articles addressing an issue for a particular product

\begin{tabular}{|c|c|c|c|c|c|}
\hline \# Paper & Product & Revenue & Delivery System & Financing & Others \\
\hline \multirow{4}{*}{1} & Government build and operate toll road & & & & 1 \\
\hline & Toll Road Operation Corporate was listed in Exchange & & & & 1 \\
\hline & Toll Road Corporation was listed in Exchange & & & & 1 \\
\hline & Joint Operation with Foreign Corporation & & & & 1 \\
\hline \multirow{2}{*}{2} & Regulator can determine maximum toll rate & & 1 & & \\
\hline & The least toll revenue present value during concession & & 1 & & \\
\hline \multirow{2}{*}{3} & Fuel Tax & & & 1 & \\
\hline & Electronic Toll Payment & & & 1 & \\
\hline 4 & Private financing initiative & & & 1 & \\
\hline 5 & Risk project financing & & & 1 & \\
\hline 6 & Uncertainty of dynamic transportation demand & & & 1 & \\
\hline 7 & Securitization & & & & 1 \\
\hline \multirow{4}{*}{8} & Cost of finance & & 1 & & \\
\hline & Bankability & & 1 & & \\
\hline & Viability & & 1 & & \\
\hline & Affordability & & 1 & & \\
\hline 9 & Earmarked tax revenue system & & & 1 & \\
\hline \multirow{2}{*}{10} & User mode selection & 1 & & & \\
\hline & Endogenously route & 1 & & & \\
\hline \multirow{3}{*}{11} & Cost escalation & & 1 & & \\
\hline & Social time preference & & 1 & & \\
\hline & Early commissioning profit & & 1 & & \\
\hline \multirow{2}{*}{12} & SPV was supported by sponsor & & & 1 & \\
\hline & Insurer to SPV & & & 1 & \\
\hline 15 & Limited equity & & & 1 & \\
\hline \multirow{2}{*}{16} & Interest rate cap & & & 1 & \\
\hline & Take out financing & & & 1 & \\
\hline 17 & Real option & & & 1 & \\
\hline \multirow{5}{*}{18} & Budget from government and local & & & 1 & \\
\hline & Local income tax & & & 1 & \\
\hline & Land transfer fee & & & 1 & \\
\hline & Self-raised funds & & & 1 & \\
\hline & Foreign capital investment & & & 1 & \\
\hline 19 & Capital market & & & 1 & \\
\hline 20 & SPV financial strength & & & 1 & \\
\hline \multirow{5}{*}{21} & Viability gap financing & & & 1 & \\
\hline & Private equity funding & & & 1 & \\
\hline & Deep discount bonds & & & 1 & \\
\hline & Take out financing & & & 1 & \\
\hline & Sinking fund depreciation & & & 1 & \\
\hline \multirow{10}{*}{22} & Advance Construction (AC) & & & 1 & \\
\hline & Partial Conversion of Advance Construction & & & 1 & \\
\hline & Matching Credit for Private Funds, Materials & & & 1 & \\
\hline & Services Donated to FA Projects & & & 1 & \\
\hline & Bond and debt instrument & & & 1 & \\
\hline & ISTEA Section 1012 Loans & & & 1 & \\
\hline & ISTEA Section 1044 Toll Investment Credits & & & 1 & \\
\hline & Special benefit assessments & & & 1 & \\
\hline & State Infrastructure Bank (SIB) & & & 1 & \\
\hline & Tax increment financing & & & 1 & \\
\hline
\end{tabular}




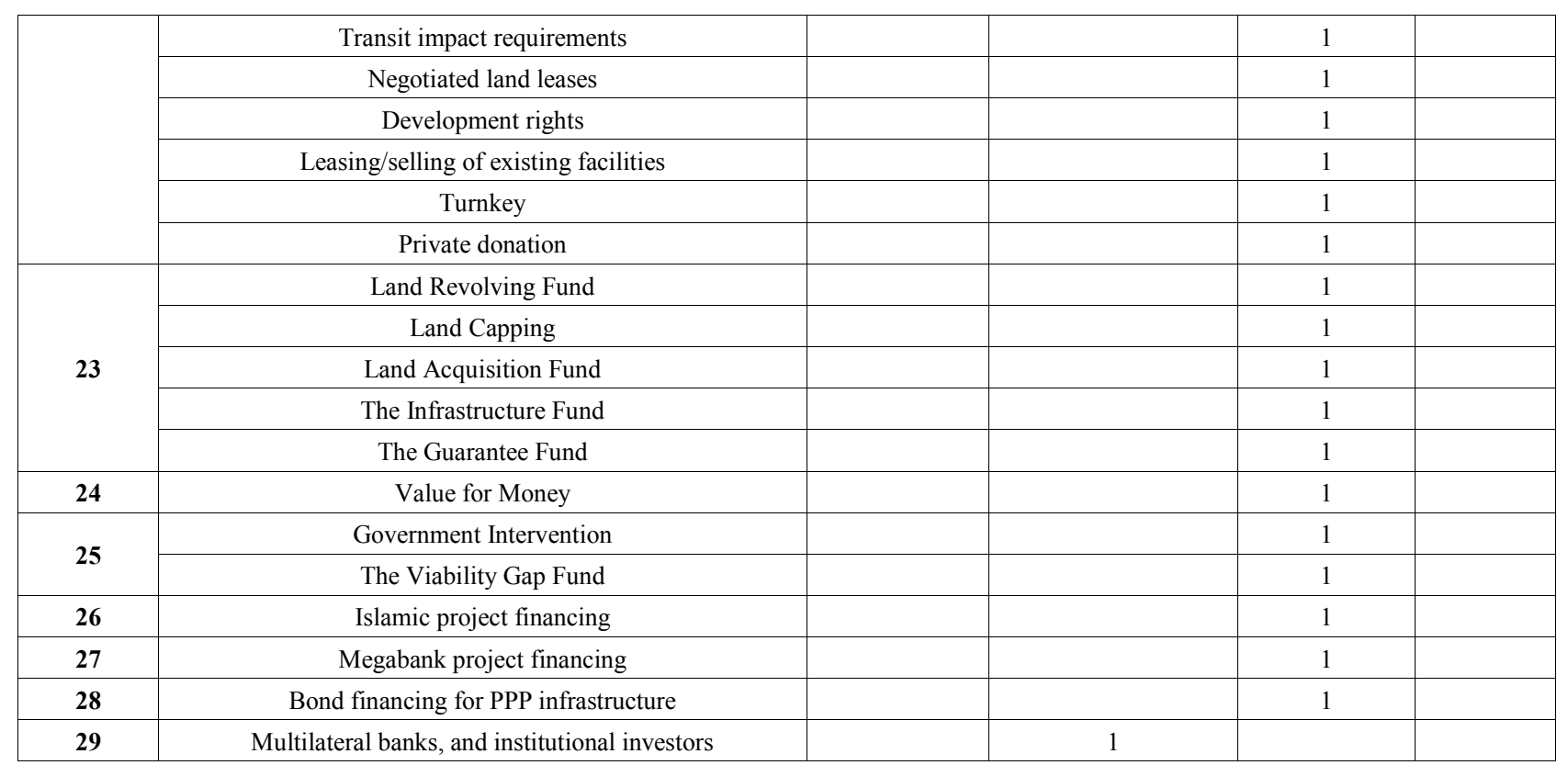

Table 5. The products studied vis-a'-vis the geographical location

\begin{tabular}{|c|c|}
\hline Country & Number of Product \\
\hline USA & 24 \\
\hline UK & 4 \\
\hline China & 9 \\
\hline Korea & 1 \\
\hline Hong Kong & 2 \\
\hline Canada & 1 \\
\hline Australia & 2 \\
\hline India & 1 \\
\hline Turkey & 14 \\
\hline Indonesia & 1 \\
\hline Nigeria & 7 \\
\hline Pakistan & 2 \\
\hline Columbia & 1 \\
\hline
\end{tabular}

\section{Results and Discussion}

A state-of-the-art literature review of TRFMs is presented in this paper, discussing the major infrastructure project financing issues for toll road financing. The aim of this study was to highlight the trends and opportunities in research that addresses the TRFMs. To meet this objective, various databases over a period of 18 years (1999-2017) were collected from the literature. The literature was systematically reviewed and classified to provide a better understanding of the research in the last two decades. In order to maintain the integrity of the overall process, a structured and fit-for-purpose systematic research process was utilized in both the collection and content analysis of the literature. The review process was inspired and guided by the principles of [23-25], considering the advantages and ignoring the disadvantages of the respective processes.

A two-step process was followed for the literature segmentation and synthesis. First, the literature was segmented according to the journals, publications per year, and countries to obtain an overview. The journals were then categorized into infrastructure project financing journals, economics \& regulation management journals, and other journals. It was found that out of 29 papers, 15 were published in infrastructure project financing journals and 8 were published in economics \& regulation management journals.

The literature was also segmented according to the countries, and it was found that most of the research was done in the USA, India, China, Japan, and Indonesia with only a limited amount of attention given to the developing countries. This was also evident from the fact that $60 \%$ of the papers addressed issues of developed countries, while only $40 \%$ focused on developing countries. This is quite similar to the research trend in other disciplines with a few exceptions. Nevertheless, it is believed that in the coming years, there will be a huge change in this trend, with a majority of research publications from Asian countries with growing economies such as India and China. These countries have some of the longest toll roads. It has been found that the second longest toll roads in the world are in China, with $45,000 \mathrm{~km}$.

In the second step, the literature was classified according to the context of the problem, methodology, product, and geographical region for an in-depth analysis of the same aspects. The research on TRFMs is in the nascent stage and is disintegrated into problematic contexts. The isolated problems with little attention given to the interdependence of the problems were addressed by these studies. The fragmented nature of the TRFMs can be attributed to this phenomenon. 
Most of the problems have been generally well-studied and explored for infrastructure project financing, but have recently gained attention for toll road financing models. It is also implicit that the research in specific problem contexts will continue to increase in the short term. Nevertheless, the requirements for integrative contributions will emerge with an increase in efforts to understand the overall phenomena of TRFMs. It is observed that the level of interest varies across the problem contexts. There are a lot of context-specific papers, especially in the delivery system and financing spheres. Only a few studies on toll road financing have explored other problems, such as revenue focus. Therefore, a huge potential exists for exploring these problems in TRFMs.

The literature was classified according to the applied methodologies to find out the theoretical orientation of the field as a whole. From this analysis, it is revealed that case studies and action research generally solved most of the problems. The methods confined modeling and simulation to areas such as problem identification and forecasting. Taking into account the relative infancy of the field, it is expected that in the future there will be an increase in the use of other methodologies. The fragmented nature of the problems is expected, even considering cross-methodological approaches. Best practices from the practitioners have not emerged in the papers. This shows the lack of universally accepted practices and the complex nature of the problem. With the increase in the literature, it is also assumed that the best practices and advanced techniques will also emerge in the infrastructure literature.

The classification, according to the production, shows that in a majority of the cases all the toll road financing products are assumed to be a single factor, with only limited attention given to the individual product characteristics. It is very important to study the products at the individual level given their factors. The consumption habits and climate of any geographical location play an important role in deciding the relative importance of toll road financing for that particular region. The study of literature across the geographic regions reveals that there is an increase in TRFM research, but it is limited mainly to a few countries. It is interesting to note that these countries have almost the same ranking for research in all other disciplines (www.scimagojr.com). There are a few exceptions, such as Indonesia, due to its commitment towards infrastructure. There is a need for research to be replicated and studied in developing nations, which are among the biggest financing models of toll road infrastructure.

The results of the state-of-the-art literature reviews on project financing models in Indonesia are shown in Table 6. They all come from the mapping of the problem context to the methodology and to the product, which shows a clear picture of the link between product-problem-methodology.

The financing model of earmarked tax revenue is funds that are obtained from vehicle taxes and fuel taxes. The revenue is utilized for land acquisitions, financial costs, or legal costs in the pre-construction and construction phases. The countries that have successfully applied this model are Japan and USA [31, 56, 55-59].

The deep discount bond financing model is funds that are obtained from financial market debt with zero coupon bonds. A country that has successfully applied this model is the USA, which borrowed 1.5 billion US dollars for infrastructure development [38, 60-63].

The take out financing (TOF) model is funds that are obtained by financial institutions, which take over a bank lender due to a construction duration of over 10-15 years, while the bank lender is only able to provide a loan of up to 5 years. India has successfully implemented this model, where financial institutions such as the India Infrastructure Finance Company Limited (IIFCL) took over the bank loan $[34,63]$.

Table 6. The results of a state-of-the-art literature review on toll road financing models in Indonesia

\begin{tabular}{|c|c|}
\hline Author's Name & Variable of Financing Models \\
\hline Nambu [32] & Earmarked tax revenue system \\
\hline $\begin{array}{c}\text { Srivastava, Lakhmani, and Sikroria } \\
{[35,39]}\end{array}$ & Take out financing \\
\hline Lakhmani and Sikroria [39] & Deep discount bonds \\
\hline Xueming [45] & Tax increment financing \\
\hline Xueming [45] & Land leases \\
\hline Xueming [45] & Deferred debt \\
\hline Xueming [45] & Private donations \\
\hline
\end{tabular}

The tax increment financing (TIF) model is funds that are obtained based on land and building taxes (PBB) and tax object sales value (NJOP) differences with respect to toll road building before and after toll road construction [44, 64-66]. The land lease financing model is funds that are obtained from toll road land property leases during the operation [44, 67-69]. The deferred debt financing model is funds that are obtained by suspension of debt payments, and are paid in the operational phase when the financial statement is positive $[44,70]$.

\section{Conclusions}

After identifying, evaluating, and synthesizing the literature review of TRFMs; using segmentation, classification based on problem context, classification based on methodology, and classification based on the product, it can be concluded that the results of the state-of-the-art literature review on project financing models in Indonesia are: an earmarked tax revenue system, take out financing, deep discount bonds, tax increment financing, land leases, deferred debt, and private donations.

Nevertheless, this study can be continued to deeply study the weaknesses and strengths of the seven outcomes and to know whether the seven models have been used in 
Indonesia or not. Finally, we can determine the most suitable TRFMs that can be applied in the development of toll road in Indonesia.

\section{Acknowledgements}

The authors would like to express gratitude to Universitas Indonesia for granting support through a PITTA scheme, in order to assist the researchers in completing this research.

\section{REFERENCES}

[1] T. Merna. Project Finance in Construction: A Structured Guide to Assessment, Wiley-Blackwell, 2010.

[2] S. Gatti. Project Finance in Theory and Practice: Designing, Structuring, and Financing Private and Public Projects, Academic Press, 2008.

[3] J. D. Finnerty. Project Financing: Asset-Based Financial Engineering 3rd Edition, John Wiley \& Sons, 2013.

[4] E. Yescombe. Principles of Project Finance, Academic Press, 2002.

[5] Jasa Marga, Jagorawi, Online available from http://www.jasamarga.com/layanan-jalan-tol/jagorawi.html

[6] Wikipedia, Jalan Tol Jagorawi, Online available from http://id.wikipedia.org/wiki/Jalan_Tol_Jagorawi

[7] A. Wibowo and B. Kochendörfer. Financial Risk Analysis of Project Finance in Indonesian Toll Roads, Journal of Construction Engineering and Management, Vol. 131, No. 9, 963-972, 2005.

[8] Ethridge: ARTBA Forecast Calls for Modest 2015 Growth, Better Roads, (2014), Online available from http://www.betterroads.com/artba-forecast-calls-for-modes t-2015growth/

[9] The World Bank, Ministry of Construction Japan. Asian Toll Road Development Program: Review of Recent Toll Road Experience in Selected Countries and Preliminary Tool Kit for Toll Road Development, p. II-4, 1999.

[10] S. Dikun. Infrastruktur Indonesia: Sebelum, Selama, dan Pasca Krisis, Bappenas, Indonesia, 2003

[11] Gautier and M. Mitra. Financing Infrastructure Under Budget Constraints, Core Discussion Paper 2003/37, Belgium, 2003.

[12] F. Nix. Alternative Road Financing Arrangements, Research conducted for the Canada Transportation Act Review, 2001.

[13] C. Harris. Infrastructure Projects: A Review of Canceled Private Projects, The World Bank-PPI, 2003.

[14] D W. Halpin and B. A. Senior. Construction Management, Fourth Edition, John Wiley \& Sons., Inc., 2012.
[15] R. Elgemony. Debt-financing Alternatives: Refinancing and Restructuring in the Lodging Industry, Cornell Hotel and Restaurant Administration Quarterly, 2002.

[16] E. Scannella. Project Finance in the Energy Industry: New Debt-based Financing Models, International Business Research, Vol. 5, No. 2, 83-93, 2012.

[17] N. G. Josephine, K.V. Gautami, and R. A. Thillai. Infrastructure Finance: A Comparative Analysis of Projects with and without Private Equity Funding, Online available from http://ssrn.com/abstract=1912321

[18] Fink. Conducting Research Literature Reviews: From the Internet to paper, SAGE Publications, 1998.

[19] M. R. H. Fitt. An Investigation of the Doctoral Dissertation Literature review: From the Materials We Use to Prepare Students to the Materials that Students Prepare, PhD Thesis, Utah State University, 2011.

[20] P. Brewerton and L. Millward. Organizational Research Methods: A Guide for Students and Researchers, SAGE Publications, 2001.

[21] C. M. Harland, R. C. Lamming, H. Walker, W. E. Phillips; N. D. Caldwell; T. E. Johnsen; L. A. Knight; J. Zheng. Supply Management; Is it a discipline? International Journal of Operations \& Production Management, Vol. 26, No. 7, 2006.

[22] P. Glasziou. Systematic Reviews in Health Care: A Practical Guide, Cambridge University Press, 2001.

[23] P. Mayring. Qualitative Content Analysis: Theoretical Foundation, Basic Procedures, and Software Solution, 2014.

[24] M. Shukla and S. Jharkharia. Agri-fresh Produce Supply Chain Management: A State-of-the-Art Literature Review, International Journal of Operations \& Production Management, Vol. 33, No. 2, 114-158, 2013.

[25] P. Mayring. Qualitative Content Analysis, Theories Methods Applications, Vol. 1, No. 2, 2000.

[26] H. H. Kassarjian. Content Analysis in Consumer Research, The Journal of Consumer Research, Vol. 4, No. 1, 1977.

[27] R. Bahl, J. F. Linn, and D. L. Wetzel. Financing Metropolitan Government in Developing Countries, Lincoln Institute of Land Policy, 2013.

[28] E. Engel, R. Ficher, and A. Galetovic. A New Approach to Private Roads, Regulation Fall. 2002.

[29] G. Roth. A Road Policy for the Future, Regulation, Vol. 26, No. 1, 54-59, 2003.

[30] S. Seoh. Innovative Application of PFI to Korea, Thesis Master MIT, 2003.

[31] T. Nambu, History of Road Development, Finance, and Investment in Japan, 2006.

[32] T. D. Chaudhuri. Methods of Financing Road Projects in India, The IUP Journal of Infrastructure, Vol. VII, No. 1, 47-55, 2009.

[33] S. T. Ng, Jingzhu X., and M. M. Kumaraswamy. Simulating the Effects of Risks on Equity Return for Concession-based Public-Private Partnership Projects, Engineering, 
Construction, and Architectural Management, Vol. 17, No. 4, 352-368, 2010.

[34] V. Srivastava. Project Appraisal in Infrastructure Financing by Indian Banks, The IUP Journal of Infrastructure, Vol. IX, No. 1, 8-16, 2011.

[35] Zhirong J. Z. and Chengxin C. Funding China's Urban Infrastructure: Revenue Structure and Financing Approach, Public Finance, and Management, Vol. 11, No. 3, 284-305, 2011.

[36] T. Erol and D. D. Ozuturk. An Alternative Model of Infrastructure Financing Based on the Capital Market: Infrastructure REITS (InfraREITs) in Turkey, Journal of Economic Cooperation and Development, Vol. 32, No. 3, 65-88, 2011.

[37] De Marco, G. Mangano, and Xin-Yu Z. Factors Influencing the Equity Share of Build-Operate-Transfer Projects, Built Environment Project and Asset Management, Vol. 2, No. 1, 70-85, 2012.

[38] P. Lakhmani and R. Sikroria. Infrastructure Financing Instruments with a Special Emphasis on Highways and Roads, International Journal of Management Research and Review, Vol. 2, Is. 9, 1668-1677, 2012.

[39] B. Brodjonegoro. Pengamanan Fiskal Melalui Pola Pembagian Risiko antara Pemerintah dan Swasta (Kapala Badan Kebijakan Fiskal, Kementerian Keuangan, 2012.

[40] L. Martin, W. Lawther, G. Hodge, and C. Greve. Internationally Recommended Best Practices in Transportation Financing Public-Private Partnerships (P3s), Public Administration Research, Vol. 2, No. 2, 1927-5188, 2013.

[41] R. Akbiyikli, D. Eaton, and A. Turner. Project Finance and the Private Finance Initiative (PFI), The Journal of Structured Finance, Vol. 12, No. 2, 67-75, 2006.

[42] P. Lahdenperä and T. Koppinen. Financial Analysis of Road Project Delivery Systems, Journal of Financial Management of Property and Construction, Vol. 14, No. 1, 61-78, 2009.

[43] L. B. Singh and S. N. Kalidindi. Criteria Influencing Debt Financing of an Indian PPP Road Project: A Case Study, Journal of Financial Management of Property and Construction, Vol. 14, No. 1, 34-60, 2009.

[44] Xueming C. Managing Transportation Financing in an Innovative Way, Management Research and Practice, Vol. 4, Issue 3, 5-17, 2012.

[45] T. Nagae and T. Akamtsu. Dynamic Revenue Management of a Toll Road Project under Transportation Demand Uncertainty, Network Spatial Economics, Vol. 6, 345-357, 2006.

[46] R. Lindsey. Prospects for Urban Road Pricing in Canada, Brookings-Wharton Papers on Urban Affairs; 2008.

[47] Li P., Zhang S., A. Talvitie, and Chen Y. New Model for Financing and Managing Highway: Asset-based Road Corporations in China, Transportation, Vol. 26, No. 1, 67-86, 1999.

[48] B. Ashuri, Jian L., and H. Kashani. A Real Options Framework to Evaluate Investments in Toll Road Projects
Delivered under the Two-Phase Development Strategy, Built Environment Project and Asset Management, Vol. 1, No. 1. 14-31, 2011.

[49] C. Dym. Principles of Mathematical Modeling, Academic Press, MA, USA, 2004.

[50] V.P. Singh. System Modeling and Simulation, New Age International, Delhi, India, 2009.

[51] M. R. Kosorok. Introduction to Empirical Processes and Semiparametric Inference, Springer, NY, USA, 2008.

[52] J. W. Creswell. Qualitative Inquiry \& Research Design: Choosing Among Five Approaches, SAGE Publications, London, 2007.

[53] P. Marshall, P. Willson, and K. de Salas. Action Research in Practice: Issues and Challenges in a Financial Services Case Study, The Qualitative Report, Vol. 15, No. 1, 76-93, 2010.

[54] C. Pagano. Proceed with Caution: Avoiding Hazards in Toll Road Privatization, St. John's Law Review, Vol. 83, No. 1, 351-394, 2009

[55] R. Carling. Tax Earmarking: Is it Good Practice? The Centre for Independent Studies, 2007.

[56] A. Athanassakos. General Fund Financing Versus Earmarked Taxes: An Alternative Model of Budgetary Choice in a Democracy, Public Choice (1986-1998), Vol. 66, No. 3, 261-278, 1990.

[57] C. Doll and H. van Essen. Road Infrastructure Cost and Revenue in Europe, Report to Internalization Measures and Policies for All External Costs of Transport (IMPACT), 2008.

[58] G. Favero. Fiscal Decentralization and Urban Public Transport, MIT Thesis, MA, USA, 2006.

[59] K. Kunz. The Use of Earmarked to Fund State and Local Infrastructure, $\mathrm{PhD}$ Thesis, University of Illinois, Illinois, USA, 2004.

[60] R.S. Varma. Capital Structure Changes and Shareholder Wealth: The Case of Deep Discount Debt, PhD Thesis, Pennsylvania State University, Pennsylvania, USA, 1987.

[61] S. Parameswaran. Fundamentals of Financial Instruments: Stocks, Bonds, Foreign Exchange, and Derivatives, John Wiley \& Sons, Hoboken, NJ, USA, 2010.

[62] A. A. Collins, A. J. Durst, H. Levebthal, and M. N. Schwarz. Deep Discount Bonds - International Financing Technique, The CPA Journal, Aug. 1982, 51-53, 1982.

[63] The India Infrastructure Finance Company Limited (IIFCL). Takeout Finance Scheme for Financing Viable Infrastructure Projects, Online available from http://www.iifcl.org/Content/mtfc.aspx

[64] T. G. Johnson and J. K. Scott. A Comprehensive Approach to the Assessment of Tax Increment Financing (TIF) Projects, Journal of Public Budgeting, Accounting, \& Financial Management, Vol. 16, No. 3, 394-412, 2004.

[65] M. Royse. Advantages \& Disadvantages of Tax Increment Financing, Economic Development Review, Vol. 10, No. 2, 84-86, 1992.

[66] S. Farris and J. Horbas. Creation vs. Capture: Evaluating the 
True Costs of Tax Increment Financing, Journal of Property Tax Assessment \& Administration, Vol. 6, Is. 4, 5-28, 2009.

[67] M. S. Jairath. Dynamics of the Land-Lease Market in Hilly Areas, Indian Journal of Agricultural Economics, Vol. 55, No. 3, 349-350, 2000.

[68] Q. Weidong and L. Xiaolong. The Journal of Real Estate Research, suppl. Special Issue on Chinese Real Estate Markets, Vol. 34, No. 3, 291-310, 2012.

[69] E.C. Hui. An Empirical Study of the Effects of Land Supply and Lease Conditions on the Housing Market, Property Management, Vol. 22, No. 2, 127-154, 2004.

[70] E. T. Nwaeze and A. Lulseged. Valuation Relevance of Allowance for Funds Used During Construction and Operating Income: The Effects of Regulatory Climates and Deregulation, Review of Quantitative Finance and Accounting, Vol. 19, No. 2, 131-153, 2002.

[71] M. Yamaguchi. Lending Behavior of Japanese Megabanks in Indonesian Project Finance Market, Review of
Integrative Business and Economics Research, Vol. 5, Is. 3, 69-86, 2016.

[72] S. O. Babatunde and S. Perera, Barriers to bond financing for public-private partnership infrastructure projects in emerging markets: A case of Nigeria, Journal of Financial Management of Property and Construction, Vol. 22, Is. 1, 2-19, 2017.

[73] E. Kalu. Infrastructure Finance Mechanism and Challenges in Nigeria, Independent Journal of Management \& Production, Vol. 6, Is. 3, 827-836, 2015.

[74] A. Javed and B. A. Fida, Islamic Project Financing in Pakistan: Current Challenges and Opportunities Ahead, Iranian Journal of Management Studies, Vol. 8, Is. 1, 47-71, 2015.

[75] J. D González-Ruiz, E. Duque and S. Botero, The Process of Funding Highway Projects in Colombia: Outlook and Challenges, Institute of Transportation Engineers. ITE Journal, Vol. 87, Is. 8, 30-35, 2017. 